\title{
LAS CARTAS NÁUTICAS DE LA ESCUELA CARTOGRÁFICA MALLORQUI- NA. ASPECTOS ARTÍSTICOS Y CONTEXTO PRODUCTIVO
}

\section{TINA SABATER REBASSA, ANTÒNIA JUAN VICENS, MAGDALENA CERDÀ GARRIGA}

UDC: $912.43(460.32) " 13 / 14 "$
$75.033 \cdot 5(460.32)$

Review

Manuscript received: 09. 11. 2015.

Revised manuscript accepted: 16. 03. 2016.

DOI: 10.1484/J.HAM.5.111354
T. Sabater Rebassa

A. Juan Vicens

M. Cerdà Garriga

Universitat de les Illes Balears

Ctra. de Valldemossa, km. 7,5

Edificio Ramon Llull

07122 Palma de Mallorca (Illes Balears)

This paper looks at Majorcan cartography in the $14^{\text {th }}-16^{\text {th }}$ centuries from a History of Art perspective. Its artistic aspects are worked on, specifcally the use of significant imagery and, above all, the style which distinguishes figurative representation. The results are explained by reference to the productive context and matters linked to the promotion and acquisition of the works are dealt with. By analysing 28 examples, prototypes and evolution of form can be seen; the inclusion of Marian images - new iconography used by the school with a large following later on - from 1464 is highlighted; and, from 1538, the introduction of hagiography - images which relate to the devotion of seafarers and which connect to the Venetian cartographic tradition. To distinguish possible sources of inspiration, data is analysed on the cartographers' training, their relationships with miniaturists and painters, their method of working and the esteem in which the office was held. Finally, the appearance of charts in inventories and at auctions is analysed, to find out about the promotional sectors and differentiate between simple examples with an intended purpose, painted charts and those which were considered as luxury items as they were made using precious materials.

Keywords: nautical charts, cartography, Majorcan school, Late Middle Ages, Gothic Painting, Mediterranean

\section{ANTECEDENTES HISTORIOGRÁFICOS}

Un apartado brillante del arte del libro en Mallorca, la cartografía, cuenta con una amplia bibliografía a nivel internacional iniciada a mediados del siglo XIX. No obstante, no ha sido recuperado para la historia del arte hasta la década de los sesenta del siglo XX. ${ }^{1}$ Hasta estas fechas los estudiosos habían valorado el interés científico e histórico de los ejemplares surgidos de la escuela cartográfica mallorquina, obras que se realizaron entre mediados del siglo XIV y finales del siglo XVII, y cuyos autores fueron, en gran medida, de origen judío, caso de los conocidos Cresques Abraham y Jafudà Cresques.

Cuando el tema se incorporó a los estudios histórico-artísticos, interesaron especialmente aquellos aspectos relacionados con los temas que se representan. La iconografía es en realidad el aspecto más destacado de unos ejemplares que, además de su función de difusores del conocimiento, tuvieron el valor añadido de haberse convertido en trabajos artísticos codiciados en su tiempo.

A este respecto, puede decirse que fueron Julio Rey Pastor y Ernesto García Camarero en su obra La cartografía mallorquina, publicada en $1960,{ }^{2}$ quienes, desde el estudio geográfico, comenzaron a prestar atención a los numerosos dibujos que incrementaron el valor informativo de las cartas. Fueron también estos autores quienes identificaron los rasgos característicos de las cartas náutico-geográficas mallorquinas, es decir, la representación de los elementos interiores de los continentes y la vocación ecuménica de una buena parte de sus ejemplares respecto a las cartas de navegar italianas, y estudiaron también su evolución a lo largo del tiempo. Además, en este contexto de estudio, ofrecieron la sistematización de ejemplares y autores que ha constituido la base de los estudios posteriores.

Más adelante, a raíz de la conmemoración del seiscientos centenario del Atlas Català de Cresques Abraham (1375, Biblioteca Nacional de París) y de la consecuente edición de facsímiles y estudios sobre esta obra, ${ }^{3}$ los estudios iconográficos se incrementaron con el interés hacia otros aspectos. Concretamente, Gabriel Llompart y Jaume Riera profundizaron en la biografía de Cresques Abraham y de su hijo Jafudà, y sobre las relaciones entre éstos y sus más importantes promotores, el rey catalano-aragonés Pere IV y su hijo, el futuro Joan I de Cataluña-Aragón. ${ }^{4}$

En el mismo año en que se publicó el estudio sobre el Atlas Catalán, Gabriel Llompart llevó a cabo un estudio más amplio, ya que estuvo referido a las cartas náuticas del siglo XV. ${ }^{5}$ Además de profundizar en el estudio iconográfico, su aportación fundamental radicó en la transcripción y análisis de la documentación hallada en los archivos mallorquines sobre los cartógrafos y su contexto artístico. Cabe destacar aquí que en su análisis se prestó atención por vez primera a las relaciones entre los cartógrafos y el arte de la pintura. Entre 1978 y 1980 publicó asimismo su tesis doctoral, La pintura medieval mallorquina. Su entorno cultural y su iconografía, ${ }^{6}$ en la cual dedica un capítulo a los miniatu-

\footnotetext{
${ }^{1}$ Para una aproximación al tema Vid. J. C. CASASAYAS TALENS, La cartografía mallorquina y la polémica de su literatura en Taula: quaderns de pensament, 2, 1983, p. 33-42.

${ }^{2}$ E. J. REY PASTOR, E. GARCÍA CAMARERO, La cartografía mallorquina, Madrid, 1960.

3 J. MATAS TORT (coord.), L'Atlas Català de Cresques Abraham, Barcelona, 1975; H.C. FREIESLEBEN (ed.), Der Katalanische Weltatlas vom Jahre 1375, Stuttgart, 1977; M. MOLEIRO RODRÍGUEZ, (ed.), Mapamundi del año 1375, Barcelona, 1983.

${ }^{4}$ G. LLOMPART I MORAGUES, Aspectos iconogràfics, en J. Matas Tort (coord.), op. cit. (n. 3), p. 41-55; J. RIERA I SANS, Cresques Abraham, jueu de Mallorca, mestre de mapamundis i de brúxoles, en J. Matas Tort (coord.), op. cit. (n. 3.), p. 14-22.

${ }^{5}$ G. LLOMPART, La cartografía mallorquina del siglo XV: nuevos hitos y rutas, en Bolletí de la Societat Arqueològica Lul.liana, 34, 1975, p. 438-465

${ }^{6}$ G. LLOMPART, La pintura medieval mallorquina. Su entorno cultural y su iconografía, 4 vols., Palma de Mallorca, 1977-1980.
} 
ristas, colectivo en el que incluye a los autores de las cartas de navegar. Años después, seguiría con la transcripción de documentación relacionada con los cartógrafos mallorquines en un artículo publicado en la revista Anuario de Estudios Medievales. ${ }^{7}$

En 1991, Jocelyn Hillgarth publicó Readers and Books in Majorca. $1229-1550,{ }^{8}$ fuente básica, aún no superada, para conocer los inventarios institucionales y privados en este ámbito cronológico y espacial. Su contribución más significativa para el tema objeto de estudio radica precisamente en ofrecer datos exhaustivos sobre los propietarios de cartas náuticas, con un análisis cuantitativo y cualitativo referido a su presencia en las colecciones de libros.

Para otras significativas aportaciones hay que esperar al año 200o, en el que se publica la obra coordinada por Agustín Hernando, denominada Cartografía mallorquina. Se trata de un vasto estudio sobre la colección de cartas náuticas de la escuela, en el que se amplía y actualiza el catálogo de Rey Pastory García Camarero. Además, cabe destacar el apartado gráfico, muy reducido en los estudios anteriores. ${ }^{9}$

Finalmente, deben mencionarse los últimos estudios -desde los campos de la historia del arte y de la historiallevados a cabo por Sandra Sáenz López y Ramón Pujades Bataller. La primera, aunque se ocupa de espacios y cronologías más amplios, ha dedicado algunos textos a cartas de navegar mallorquinas, profundizando especialmente en sus aspectos iconográficos. ${ }^{10}$ Aquí interesará destacar algunas apreciaciones de carácter estilístico, referidas a las cartas náuticas de cronología avanzada, concretamente del siglo XVI. Pujades Bataller, dedicó su tesis doctoral al estudio de la producción cartográfica en el Mediterráneo occidental, por lo que los ejemplares de cartógrafos mallorquines encuentran amplio espacio en sus publicaciones. Por su interés para nuestro estudio, destacamos especialmente el monográfico sobre la carta náutica de Gabriel de Vallseca de 1439."

\section{OBJETIVOS Y MATERIALES DE ESTUDIO}

La aproximación de las autoras al tema de estudio se ha llevado a cabo a partir de dos objetivos independientes aunque interrelacionados. Tal como se precisa en el título del artículo, el análisis estilístico ha sido uno de los campos en que se ha trabajado. En este sentido, pretendemos trazar una evolución de las cartas atendiendo a sus aspectos estrictamente figurativos. Paralelamente, se ha considerado que, para una plena comprensión de los resultados, era necesario ampliar los conocimientos existentes sobre las relaciones entre la cartografía, la miniatura y la pintura sobre tabla de la escuela mallorquina. Este trabajo ha supuesto incidir en el contexto productivo, un apartado que se ha conectado, a su vez, con cuestiones que se vinculan a la promoción y adquisición de las obras. Al respecto, pensamos que el material documental deja aún un margen relevante para la interpretación, cara a la corrección de ciertas apreciaciones y a la ampliación de las mismas, especialmente por lo que atañe a los usos y funciones de las cartas de navegar. Por lo tanto, el análisis propiamente artístico y la interpretación documental han sido los instrumentos utilizados para la consecución de los objetivos que se han planteado en este estudio.

Las cartas de navegar de la escuela mallorquina salieron de la isla de Mallorca desde el mismo momento de su realización. En primer lugar, por el rango de algunos de sus promotores, caso de la monarquía catalano-aragonesa que las encargó expresamente para su uso y también como obsequio. En otros, porque fueron compradas en Mallorca por algunos mercaderes y patrones de navío de origen italiano. En 1391, a raíz del asalto a la judería de la Ciutat de Mallorca, por la dispersión de algunos de sus artífices a otros lugares del Mediterráneo. A principios del siglo XVI, a causa de la segunda expulsión de conversos, y también por la pérdida del papel protagonista del Mediterráneo como espacio económico. Finalmente, por la dispersión patrimonial que ha afectado a todas las artes desde el siglo XIX, y muy especialmente al campo del libro.

Las cartas de navegar, algunas Atlas o Mapamundis, de la escuela mallorquina tienen dos peculiaridades. Son obras que, en su mayoría, presentan datos sobre autor, cronología y lugar de realización. Por otra parte, como es sabido, se distinguen de los portulanos porque además de información gráfica sobre las costas y sus puertos, consta información geográfica sobre los continentes conocidos. A partir del Atlas Catalán, fue también común que estuviesen pintadas, y que incluyesen los accidentes orográficos e hidrográficos, ciudades amuralladas, fauna, imágenes de monarcas y otros, escudos y banderas, además de leyendas explicativas. Se ha subrayado también, concretamente por lo que se refiere a elementos geográficos, que algunos de sus rasgos específicos en la representación se mantuvieron a lo largo del tiempo. ${ }^{12}$

En nuestro estudio se manejarán, como es lógico, aquellas cartas náutico-geográficas que contienen elementos figurativos. Hemos trabajado un total de veintiocho ejemplares. El primero el Atlas Català de 1375, como único exponente del siglo XIV. Trece ejemplares del siglo XV, nueve de ellas realizadas en Mallorca, una en Nápoles por parte de un autor mallorquín y otras tres sin lugar de realización conocido. Las catorce restantes están datadas en el siglo XVI: seis de ellas

\footnotetext{
${ }_{7}$ G. LLOMPART, Registro de los cartógrafos mallorquines activos en el puerto de Mallorca, en Anuario de Estudios Medievales, 27/2, 1997, p. 1117-1148.

8 J. N. HILLGARTH, Readers and books in Majorca: 1229-1550, 2 vols., Paris, 1991.

9 A. HERNANDO, et al., Cartografía mallorquina, Barcelona, 2000.

Por lo que respecta al apartado gráfico, también es destacable la obra de A. GINARD BUJOSA, La cartografia mallorquina a Mallorca, Palma de Mallorca, 2002, en el que se hace, principalmente, un estudio histórico-descriptivo de las cartas conservadas en la isla.

1o S. SÁENZ-LÓPEZ PÉREZ, La carta náutica de 1563 de Mateo Prunes, en Piezas del mes. Museo Naval de Madrid, Madrid, 2006, p. 176-192; S. SÁENZLÓPEZ PÉREZ, El portulano, arte y oficio en M. Cuesta Domingo y A. Surroca Carrascosa (ed.), Cartografía medieval hispánica. Imagen de un mundo en construcción, Madrid, 2009, p. 111-134; S. SÁENZ-LÓPEZ PÉREZ, La pluralidad religiosa del mundo en el siglo XV a través de la carta náutica de Mecia de Viladestes (1413), en Anuario de Estudios Medievales, 22, 2012, p. 389-404; S. SÁENZ-LÓPEZ PÉREZ, La cartografía náutica bajomedieval y el arte de su realización, Cantabria, 2015.

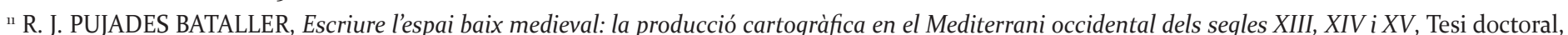
Universitat de València, 2005; R. J. PUJADES BATALLER, Les cartes portolanes: la representació medieval d'una mar solcada, Barcelona, 2007; R. J. PUJADES BATALLER, La carta de Gabriel de Vallseca de 1439, Barcelona, 2009.
}

${ }^{12}$ E. J. REY PASTOR, E. GARCÍA CAMARERO, op. cit. (n. 2), p. 21-30. 


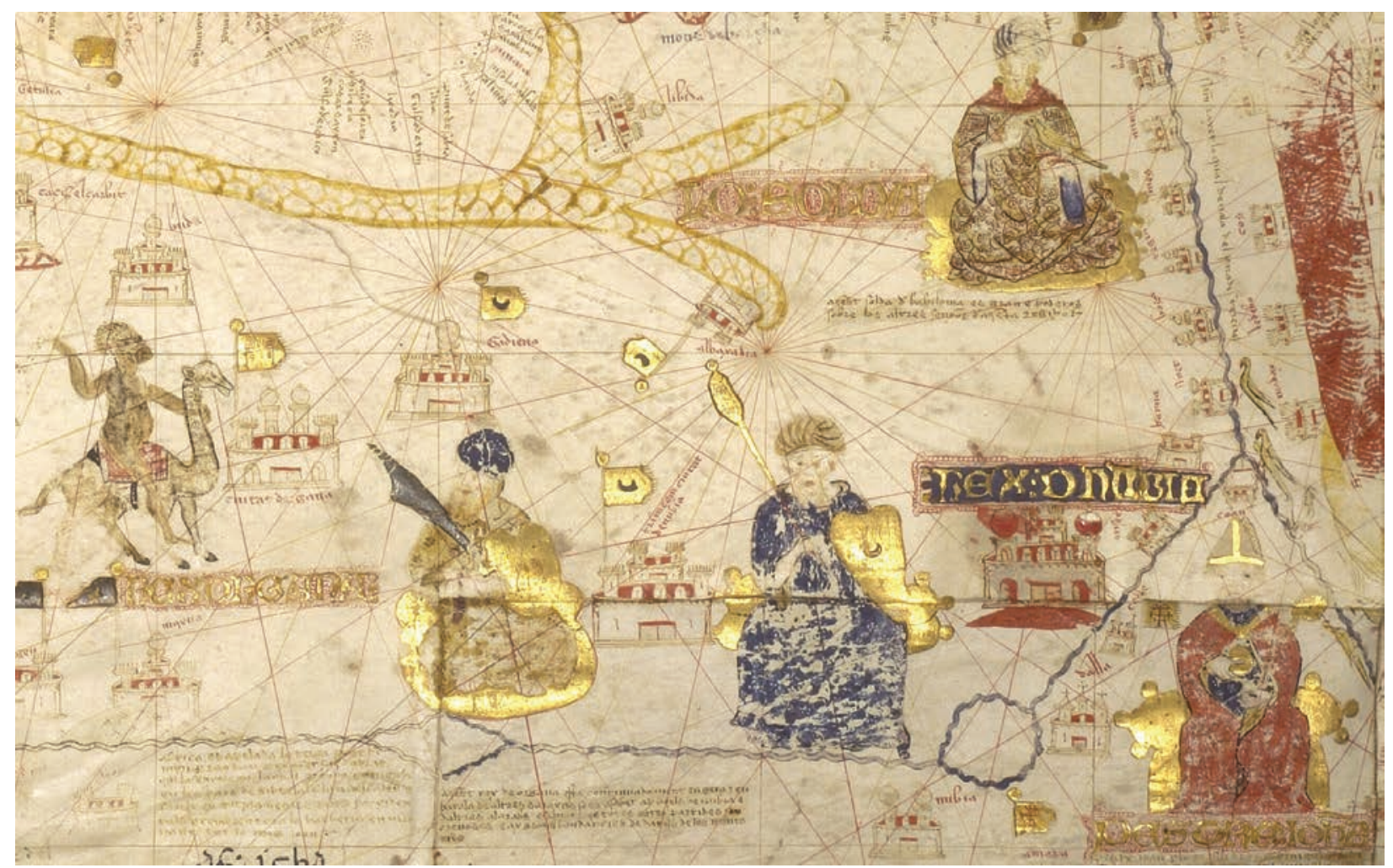

Fig. 1: Carta de Macià de Viladestes. Hecha en Mallorca en 1413. Bibliothèque nationale de France. (Fuente: Wikimedia Commons)

se firmaron en Messina, una en Nápoles, una en Barcelona, una en Génova, cuatro en Mallorca y una sin referencia sobre lugar de ejecución. Remitimos al apéndice que se incluye como anexo del texto donde se incluye un listado con los nombres y datos de cada una de ellas.

\section{ASPECTOS ARTÍSTICOS}

Como ha sido señalado, el Atlas Català sirvió de prototipo básico para los contenidos iconográficos de las cartas posteriores, ${ }^{13}$ aunque, al igual que sucedió con la incorporación de nuevos conocimientos geográficos, los ejemplares se modernizaron adoptando las novedades que se dieron en las artes del color a lo largo de la época. No obstante, cabe indicar que lo hicieron siempre con significativo retraso respecto a los modelos vigentes en la miniatura, la pintura mural y sobre tabla. Este rasgo parece que se dio desde los inicios, puesto que en el Atlas Català de 1375 se despliegan aún prototipos franco-góticos en un período muy tardío en su contexto. ${ }^{14}$ Efectivamente, la imagen del Homo Signorum que se incluye en el calendario de la primera tabla está vinculada a la faceta culta de estos modelos, los cuales posiblemente procedían de un taller familiar que, como comentaremos más adelante, se remontaban a la primera mitad del siglo XIV. En cambio, parece evidente que cuando Cresques Abraham tuvo que afrontar la representación de nuevos motivos, sin referentes previos, los resultados tuvieron un carácter secundario en cuanto a calidad de realización. En definitiva, presentan un tono popular que también será frecuente en las obras posteriores.

El eco más claro del Atlas Català lo tenemos en la carta náutica de Macià Viladestes, hecha en Mallorca en 1413, por lo tanto casi cuarenta años más tarde. Ello es evidente en la representación de los monarcas, de la fauna y en la esquematización de las ciudades (fig. 1). Ahora bien, se observa también que han aumentado los aspectos pictóricos y que, por lo tanto, se recogen fórmulas italianas que conocemos en las artes del color de Mallorca desde inicios del siglo XIV y que se prolongaron a lo largo de la centuria. Aún sin poder ser concluyentes por la posible pérdida de ejemplos significativos, puede decirse que las fuentes de Macià Viladestes fueron la propia cartografía y, muy puntualmente, la pintura sobre tabla, ya que los escasos libros ilustrados de la segunda mitad del siglo XIV que se han conservado no presentan ninguna relación.

Gabriel de Vallseca realizó varias cartas náuticas con elementos figurativos. Entre ellas, centraremos el discurso en dos obras de especial relevancia por la cantidad de motivos que presentan y su particular calidad pictórica. La primera está firmada y fechada en Mallorca en 1439, la segunda es una obra atribuida que también se hizo en la isla en torno a 1440. En ambas se da un cambio cualitativo notable en los aspectos artísticos respecto al Atlas Català y a la carta de Viladestes. Concretamente, tal como advirtió Pujades, se tomaron las tiendas del Atlas Català y se utilizaron como marco para las efigies de monarcas, un procedimiento que, además de su valor espacial, sirvió para destacar el status. ${ }^{15}$ Añadimos que en la carta de 1439 se utilizan únicamente los palios, en lugar de las tiendas, para los cuales encontramos la fuente de inspiración en los draps d'honor, tan frecuentes en la pintura catalano-mallorquina desde mediados del siglo XIV. También las posturas presentan una mayor variedad en ambos ejemplares, y el tratamiento de los marcos y de los tejidos aumenta las connotaciones ornamentales de la

\footnotetext{
${ }^{13}$ Ibidem, p. 23.

${ }^{14}$ J. AINAUD DE LASARTE, Visió de conjunt, en J. Matas Tort (coord.), op. cit. (n. 3), p. 57.

${ }^{15}$ R. J. PUJADES BATALLER, op. cit., (n. 11), 2009, p. 134-135.
} 


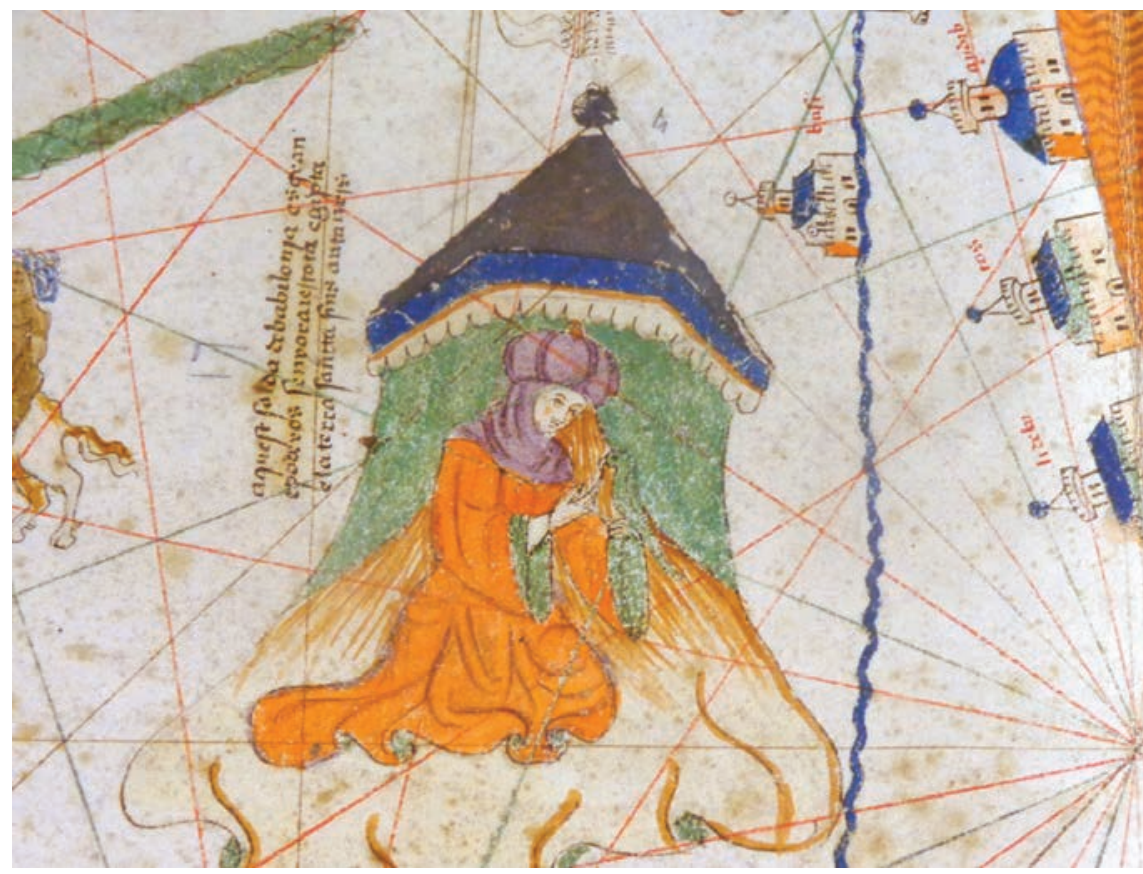

Fig. 2: Carta atribuida a Gabriel de Vallseca. Hecha en Mallorca c. 1440. Biblioteca Nazionale, Firenze.

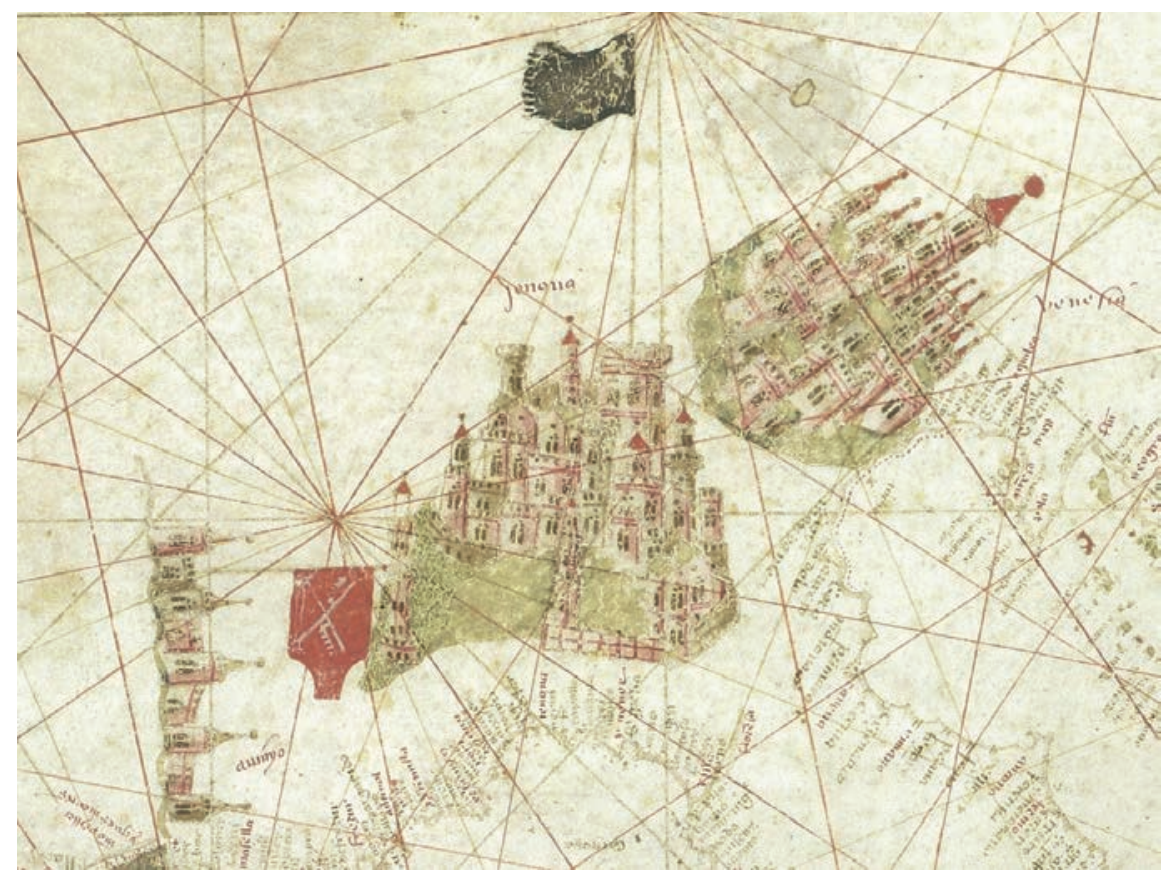

Fig. 3: Carta de Gabriel de Vallseca. Hecha en Mallorca en 1447. Bibliothèque nationale de France. (Fuente: Wikimedia Commons)

pintura (fig. 2). Si a ello sumamos los colores saturados y contrastados podemos concluir diciendo que Vallseca acogió los rasgos definitorios del llamado gótico internacional, una etapa en las artes del color consolidada en la pintura mallorquina desde 1400 y de especial relevancia en la trayectoria de la escuela.
En relación a otros aspectos, destaca un mayor interés, aunque aún puntual, en la representación de elementos distintivos de las ciudades. Es el caso, concretamente, de Génova, ya que en la carta de 1440 se aprecia el característico puerto de la ciudad, en el que claramente resaltan el faro, el arco del puerto, el muelle y el desembarcadero. Cabe señalar también en estas cartas y en otras de Vallseca que no contienen otros motivos figurativos (1447), la incipiente introducción de elementos de tipología nórdica para representar no sólo ciudades mediterráneas sino también del norte de África. Concretamente, observamos la acumulación de torres circulares rematadas con chapiteles en los dibujos de Génova, Venecia y las ciudades del Magreb (fig. 3). Parece ser que estas características en el diseño de las ciudades fueron tomadas por Vallseca de las cartas del genovés Battista Beccari (1426), según aprecia Pujades. El autor señala que se introdujeron en la cartografía mallorquina por mano de Gabriel Vallseca y de Pere Rossell, en una cronología similar, y que se perpetuaron en los exponentes posteriores. ${ }^{16}$

Como señalaron Rey Pastor y García Camarero, la carta náutica atribuida a Vallseca que se conserva en Florencia -es decir, la datada en torno a $1440-$ ofrece un nuevo prototipo para la representación de los vientos, mediante la inclusión de unas cabezas de hombre simbolizando los eolos. ${ }^{17}$ Pujades, comentó también que las imágenes de los vientos mayores ya aparecen en la carta de 1439 del mismo autor, y que se convirtieron en un motivo ornamental característico de las cartas de Vallseca, transmitiéndose a cartas posteriores, como algunas de Pere Rossell..$^{18}$

La influencia de Vallseca sobre cartógrafos posteriores, a tenor del análisis que hemos efectuado, no se limitaría a lo ya señalado sino que se extendería a otros motivos. Es el caso de los marcos para las figuras regias en forma de palio o tienda que se verán de nuevo en algunas cartas posteriores, concretamente en las de Pere Rossell (1464, 1465y 1466) y en la de Jaume Russo (1533). En otros ejemplares, no obstante -siguiendo con las figuras regias-, no se seguirá el prototipo iniciado por Vallseca sino que se seguirá con la pauta marcada por el Atlas Català. ${ }^{19}$ Así pues, puede decirse que el trabajo de Vallseca representó un nuevo prototipo más completo, detallado y pictórico respecto a la obra de los Cresques, que, sin embargo, se siguió utilizando.

En definitiva, las obras de Gabriel de Vallseca demuestran que se trata de un autor especialmente diestro en la

\footnotetext{
${ }^{16}$ Ibidem, p. 136.

${ }^{17}$ Calificada en su día de anónima por los autores, E. J. REY PASTOR, E. GARCÍA CAMARERO, op. cit. (n. 2), p. 33. Cabe decir que, si bien de manera más primaria, la representación antropomorfa de los vientos se aprecia ya en las cartas de Pierrino Vesconte (1327), Angelino Dulcert (1339) o de los hermanos Pizzigani (1367): S. SÁENZ-LÓPEZ PÉREZ, El portulano, arte y oficio en M. Cuesta Domingo y A. Surroca Carrascosa (coord.), Cartografía medieval hispánica. Imagen de un mundo en construcción, Madrid, 2009, pàg. 119.

${ }^{18}$ R. J. PUJADES BATALLER, op. cit., (n. 11), 2009, p. 136-137.

${ }_{19}$ Carta de Jaume Bertran de 1482; Carta de Jaume Olives de 1564.
} 
ilustración, que siguió bebiendo de la fuente cartográfica aunque modernizó el lenguaje de acuerdo a modelos internacionales de origen franco-flamenco. Los encontramos en ejemplares vinculados total o parcialmente a la miniatura catalana (Rafel Destorrents, Misal de Santa Eulàlia 1403; Breviario Rey Martín 1398-c.1410) del primer decenio del siglo XV. Estos modelos se siguieron cultivando en pintura en años posteriores, si recordamos las escasas obras que se conservan del catalán Joan Mates (1408-1429). Cabe preguntarse cómo conoció Vallseca estas pautas, y para ello recordar su origen catalán y su presencia en Mallorca documentada entre 1433 y $1471 .^{20}$ Parece evidente que llegó en una edad adulta y que, por lo tanto, pudo traer consigo unos modelos que son ajenos al desarrollo de la pintura mallorquina de su tiempo. Como fue tónica constante, Vallseca acogió pautas que resultan retardatarias en 1440 .

La influencia de la cartografía veneciana sobre la escuela mallorquina ha sido ya indicada por Pujades, por lo que respecta a las orlas decorativas que enmarcan las obras de Gabriel de Vallseca. ${ }^{21}$

En relación a la influencia de las cartas náuticas venecianas sobre las mallorquinas, queremos destacar la asimilación, aunque tardía, de elementos hagiográficos que, como han destacado los estudios sobre cartografía italiana, fueron propios de los atlas venecianos desde sus inicios. ${ }^{22}$ En efecto, es sabido que desde el Atlante Correr de 1318, obra de Pietro Vesconte, fue común la incorporación de imágenes de los evangelistas y otros santos en los ángulos de los folios de pergamino, figuras que estaban vinculadas a las devociones populares del ambiente marinero. En 1538, Bartomeu Olives incluyó la imagen de busto de san Nicolás sobre la representación del mar Cantábrico. En 1561, Mateu Prunes ubicó en el cuello de la carta las figuras de cuerpo entero de san Nicolás, santa Clara y san Telmo (fig. 4). Y en 1564, de nuevo Jaume Olives dibujó las imágenes de san Antonio abad y san Telmo, flanqueando una imagen mariana. Tanto los Prunes ${ }^{23}$ como los Olives u Oliva, como se comentará más adelante, fueron sagas de cartógrafos mallorquines que trabajaron en la isla y otros lugares del Mediterráneo.

Al igual que ocurrió en Venecia, los santos Nicolás y Telmo tienen antigua tradición en la devoción popular vinculada a las gentes de mar de Mallorca, es decir, pescadores, marineros y mercaderes. ${ }^{24}$ San Nicolás tuvo iglesia propia en Porto Pi desde inicios del siglo XIV, y se le dedicó una escultura en la torre del ángulo suroeste de la Lonja de Palma por expreso deseo de los prohombres del Colegio de la Mercadería, quienes, en el contrato firmado con Guillem Sagrera en 1426, especificaron que se debía ubicar en esta torre, mirando hacia la iglesia de San Nicolauet de Porto Pi. ${ }^{25}$ San Telmo fue patrono del gremio de marineros o navegantes, integrado por pilotos y patrones de embarcaciones, quienes le dedicaron un oratorio a finales del siglo XIV contiguo al puerto, en terrenos próximos al solar donde se erigiría la Lonja de Palma pocos años después. ${ }^{26}$ Esta iglesia sería reconstruida en el siglo XVII y finalmente trasladada en 1947 a su actual ubicación, siempre cercana al mar. A santa Clara, también patrona de navegantes, se le dedicaría también una escultura en el exterior de la Lonja, concretamente en la torre sudeste que mira hacia el convento

\footnotetext{
${ }^{20}$ R. J. PUJADES BATALLER, op. cit., (n. 11), 2009, p. 96-101.

${ }^{21}$ Ibidem, p. 137-138, 142.

${ }^{22}$ T. CAMPBELL, Portolan Charts from the late Thirteenth Century to 1500, en J. B. Harley y D. Woodward (ed.), Cartography in Prehistoric, Ancient, and Medieval Europe and the Mediterranean. The History of Cartography, Chicago, 1987, vol. 1, p. 398-401; P. FALCHETTA, Marinai, mercanti, cartografi, pittori. Ricerche sulla cartografia nautica a Venezia (sec. XIV-XV), en Ateneo Veneto, 182, 1995, p. 7-109; L. DE MARCHI, Come antiche preghiere. Gli atlanti veneziani del Vesconte e il loro apparato figurativo, en Storia della miniatura (en prensa). Agradecemos a Laura de Marchi que nos haya dejado consultar este artículo y en general sus orientaciones sobre el tema.

${ }^{23}$ Sobre la familia de los Prunes, cuya actividad de desarrolló entre 1532 y 1561 véase: G. DE REPARAZ, Els Prunes, cartògrafs catalans dels segles XVI i XVII, en Estudis Universitaris Catalans, 13, 1928, p. 324-337; G. CARACI, A propósito di alcune carte nautiche della Biblioteca Nazionale di Parigi, en Estudis Universitaris Catalans, 14, 1929, p. 259-278; E. J. REY PASTOR y E. GARCÍA CAMARERO, op. cit. (n. 2), p. 95-100; S. SÁENZ-LÓPEZ PÉREZ, op. cit. (n. 10), 2006 ${ }^{24}$ El estudio sobre la iconografía hagiográfica en Mallorca, en conexión con sus aspectos devocionales y con la cultura popular, ha sido estudiado especialmente por G. LLOMPART, op. cit. (n. 6), v. 2. En relación a los santos relacionados con el mar en ámbito catalán, véase también M. BARNIOL, Patrons and Advocates of the Sailors. The Saint and the Sea in Catalan Gothic, en Imago Temporis. Medium aevum VI, 2012, p. 249-276.

${ }_{25}$ El contrato firmado entre el Colegio de Mercaderes y Guillem Sagrera puede consultarse íntegramente en G. ALOMAR, Guillem Sagrera y la arquitectura gótica del siglo XV, Barcelona, 1970.

${ }^{26}$ B. QUETGLAS GAYÁ, Los gremios de Mallorca. Siglos XIII al XIX, Palma, 1939, p. 145-157; M. BARCELÓ CRESPÍ, El raval de mar de la ciutat de Mallorca, segles XIII-XV, Palma, 2012, p. 117.
} 


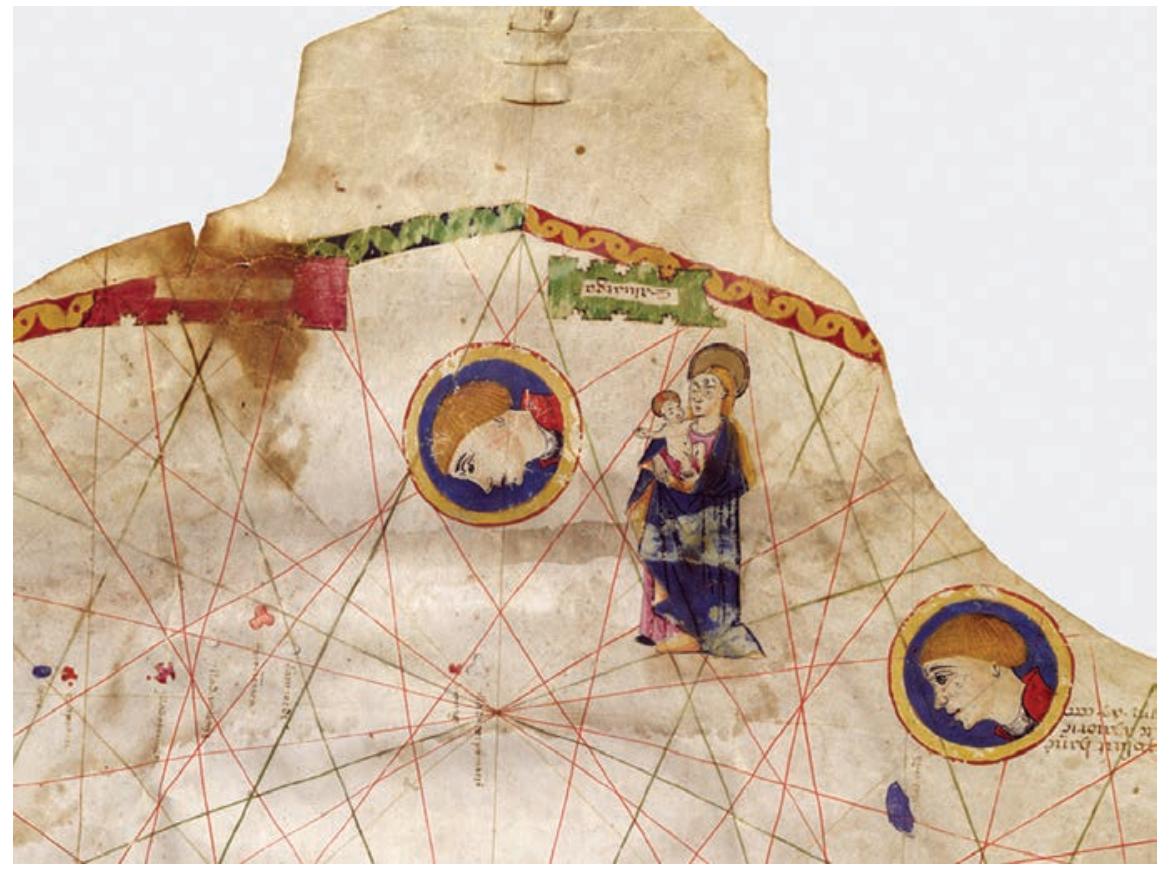

Fig. 5: Carta de Pere Rossell. Hecha en 1466 en Mallorca. James Ford Bell Library, University of Minnesota. (Fuente: Wikimedia Commons)

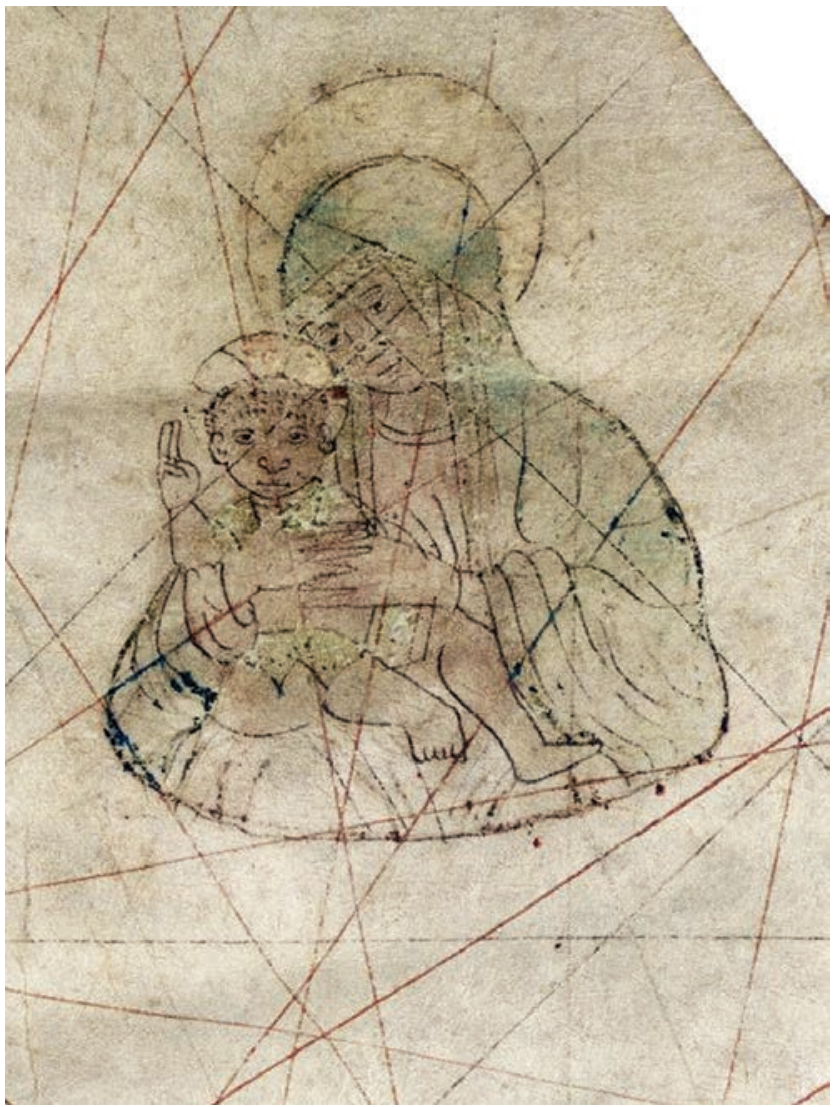

Fig. 6: Carta de Jaume Russo. Firmada en Messina en 1533. Nationaal Archief, Nederland. (Fuente: Wikimedia Commons)

de las clarisas de Mallorca. Puede ser significativo que el Colegio de Mercaderes quisiera dedicar la fachada sur de su edificio, frente al mar, a dos de los santos vinculados a estas actividades. En cuanto a san Antonio abad, en Mallorca su devoción estuvo ligada especialmente a las actividades del campo, sin embargo, como es sabido a veces ha sido invocado como protector de los barcos a causa de su papel taumatúrgico contra el ergotismo. Los tres ejemplares de cartógrafos mallorquines presentan estas representaciones hagiográficas con sus atributos habituales: san Nicolás y san Telmo vestidos como obispos, portando las tres manzanas y el barco respectivamente, santa Clara con el libro de la regla y el báculo de abadesa. No obstante, en la carta de Bartomeu Olives de 1538 san Nicolás aparece también con una palmatoria, al igual que santa Clara en la carta náutica de Mateu Prunes de 1561, un atributo poco habitual que sin duda tuvo que ver con su papel de guía para quienes debían arribar a puerto.

Como hemos aludido en párrafos anteriores, la carta de Jaume Olives de 1564 cuenta también con una imagen de la Virgen con el Niño, dibujada en pie sobre una nube. Las representaciones marianas en las cartas de navegar hechas por mallorquines aparecen, según los ejemplos que se conocen, desde 1464. Como imagen devocional única aparece en las

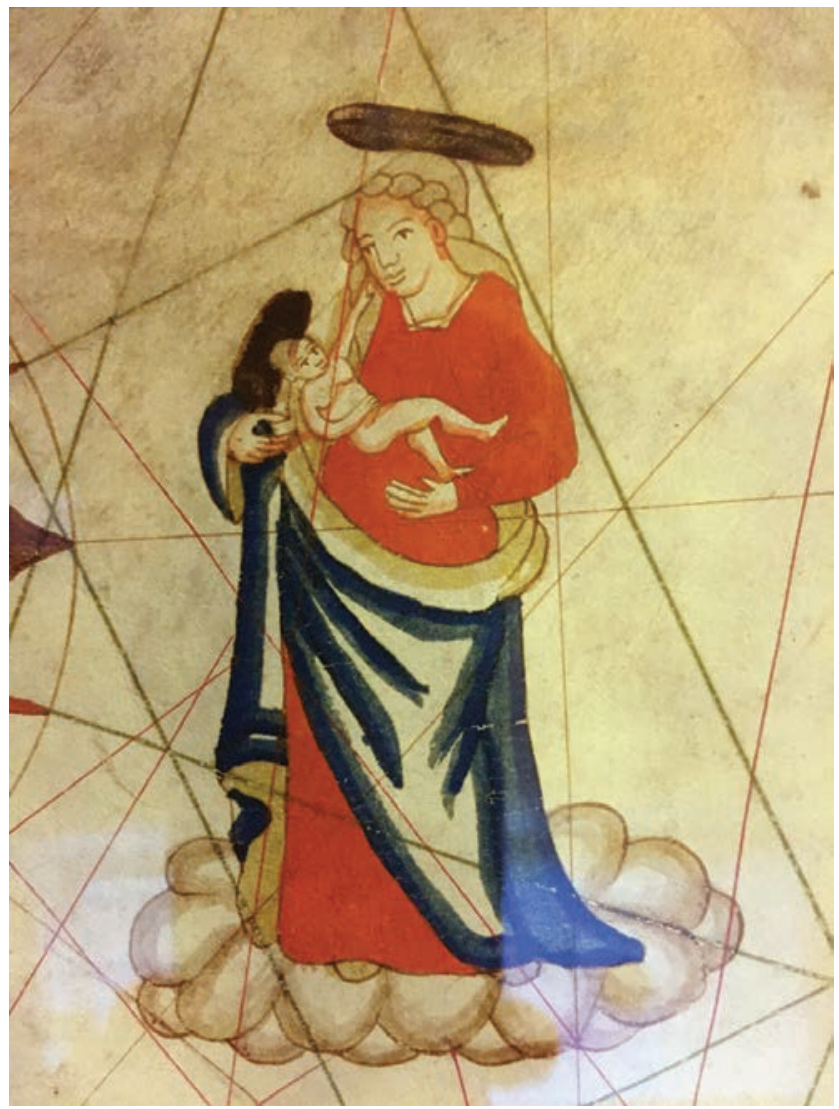

Fig. 7: Carta de Jaume Olives. Firmada en Barcelona en 1571. Biblioteca de la Fundación March de Palma.

cartas de Pere Rossell de 1464, ${ }^{27} 1465$ y 1466 (fig. 5), en la de Arnau Domènech de 1486, al igual que en la de Jaume Bertran de 1489, las de Mateu Prunes de 1563 (fig. 10) y 1571, las de Pere Russo de 1516 y de Jaume Russo de 1533 (fig. 6) y 1535 y, finalmente, en la de Jaume Olives de 1571 (fig. 7). En las

${ }^{27} \mathrm{H}$. Winter indicó que Pere Rossell fue el primero que introdujo una imagen mariana en las cartas de navegar (que no atlas), concretamente en la de 1464: H. WINTER, Petrus Roselli, en Imago Mundi, 1952, p. 6. 
cartas del siglo XV, la Virgen aparece siempre en pie en la zona del cuello de la carta, en la de Jaume Bertran sobre el atributo de la media luna. A partir del siglo XVI, se mantiene la representación de imágenes marianas en esta zona de la carta pero algunas de ellas presentan ciertas particularidades iconográficas. Es el caso de las cartas de Mateu Prunes de 1563 (fig. 10) y de 1571. En la primera, la Virgen aparece flanqueada por dos embarcaciones -en alusión a la navegación atlántica-, mientras que en la segunda se la representa en actitud amenazante, blandiendo un bastón con el que ataca al diablo que pretende dañar al que ha sido identificado como el autorretrato del cartógrafo. $^{28}$

Las cartas de navegar que se han citado datadas en el siglo XV, contienen en todos los casos imágenes de tono popular, al margen de los prototipos seguidos para la representación de las efigies regias, como se ha comentado con anterioridad. No obstante, respecto a las cartas de Gabriel de Vallseca, notamos cambios en la tradición del estilo internacional: concretamente, las figuras marianas muestran de nuevo el eje vertical en la composición, así como la amplitud de formas que fue tónica en los retablos pictóricos mallorquines en las décadas centrales del siglo y hasta 1480. ${ }^{29}$

Las cartas del 1500 nos introducen en las pautas de la estética renacentista. Ello es fácilmente comprobable en las representaciones marianas, como es el caso de las cartas de Jaume Olives de 1564 y 1571, en las cuales la figura del Niño adopta claramente esta tipología, aunque es especialmente relevante en los ejemplares que adoptan la imagen mariana de busto. Éstas se encuentran en las cartas de Pere Russo de 1516 y de Jaume Russo de 1533 (fig. 6) y 1535 , las tres realizadas en Messina. Los Russo eran cartógrafos de origen valenciano, establecidos en Mallorca que acabaron trabajando en Sicilia según las pautas de la escuela mallorquina..$^{30} \mathrm{En}$ este punto no podemos sino recordar la gran influencia de los modelos flamencos sobre los pintores del sur de Italia y, específicamente, las Madonnas de busto que fueron típicas en la pintura del siciliano Antonello da Messina.

En atención a los datos que se han expuesto, cabe colegir que la introducción de las imágenes marianas en las cartas náutico-geográficas fue obra de cartógrafos mallorquines, unas nuevas pautas que se transmitirían en el espacio y en el tiempo. Concretamente se encuentran en las cartas del genovés Vesconte Maggiolo de 1541 y 1547 y, un siglo después, en las obras hechas en Messina en 1639 por Placido Caloiro

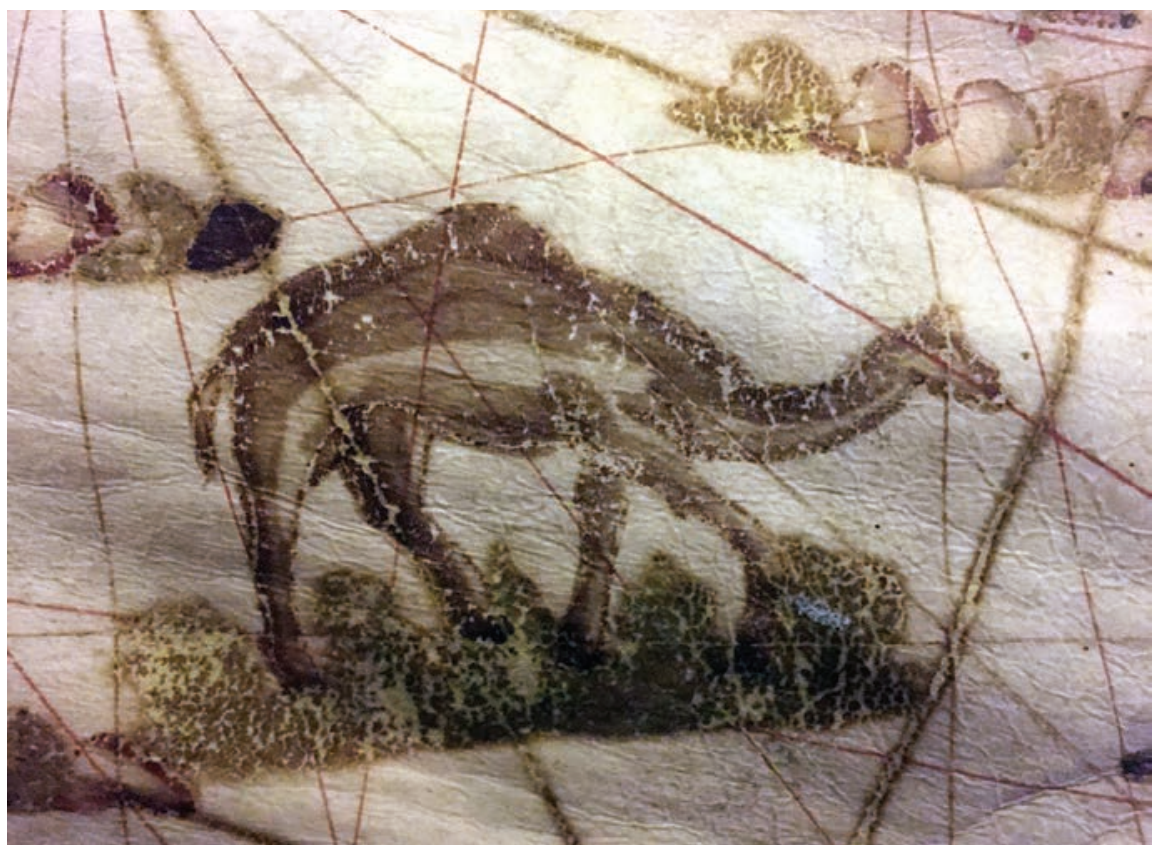

Fig. 8: Carta de Jaume Olives. Firmada en Nápoles en 1564. Biblioteca de la Fundación March de Palma.

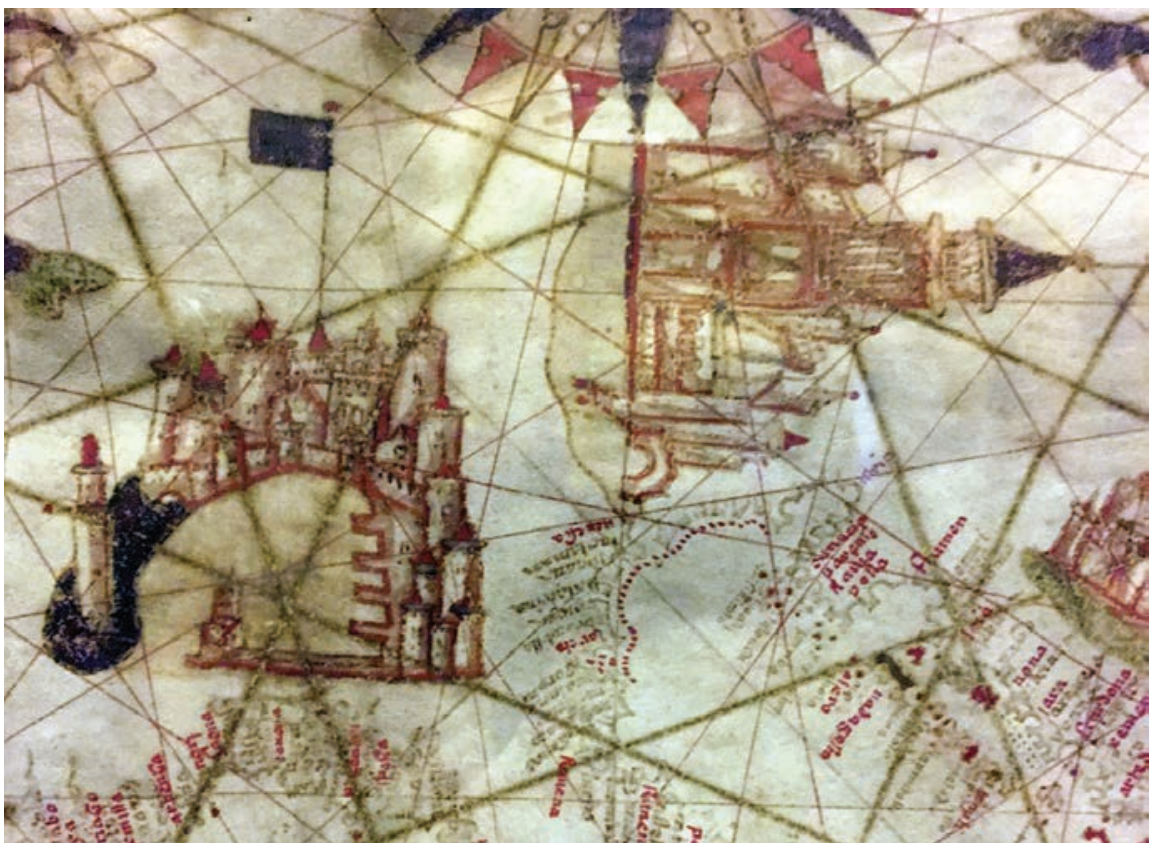

Fig. 9: Carta de Jaume Olives. Firmada en Nápoles en 1564. Biblioteca de la Fundación March de Palma.

e Oliba, supuesto miembro de la saga de los Olives u Oliba, a quienes trataremos más extensamente en el siguiente apartado de este texto.

Las obras del siglo XVI presentan, además, otras particularidades. Como se ha dicho, la figuración de las ciudades gana en detalles verosímiles y, por lo tanto, pierden el carácter estereotipado que caracterizaba este elemento en las cartas náuticas. ${ }^{31}$ Añadimos que ello también se advierte en la representación de la fauna (fig. 8), que pierde el carácter

\footnotetext{
${ }^{28}$ Para la carta de 1563 véase S. SÁENZ-LÓPEZ PÉREZ, op. cit. (n. 10), 2006, p. 185. Para la carta de 1571: L. SECCHI, Testimonianze liguri della cartografía náutica spagnola della seconda metà del cinquecento e del primo seicento, en Atti del Convengo Spagna e Toscana: la cartografia nautica di due paesi mediterranei nei secolo XVI e XVII, Pisa, 1985, p. 220-221; S. SÂENZ-LÓPEZ PÉREZ, op. cit. (n. 10), 2006, p. 178.

${ }_{29}$ T. SABATER, La pintura mallorquina del segle XV, Palma, 2002, p. 225-320.

${ }^{30}$ E. J. REY PASTOR, E. GARCÍA CAMARERO, op. cit. (n. 2), p. 46, 92-95.

${ }^{31}$ La introducción de elementos definitorios de determinadas ciudades ya aparece en cartas anteriores (S. SAÉNZ-LÓPEZ PÉREZ, op. cit. (n. 10), 2009, p. 131), sin embargo, cabe decir que estos todavía presentaban un carácter estereotipado.
} 


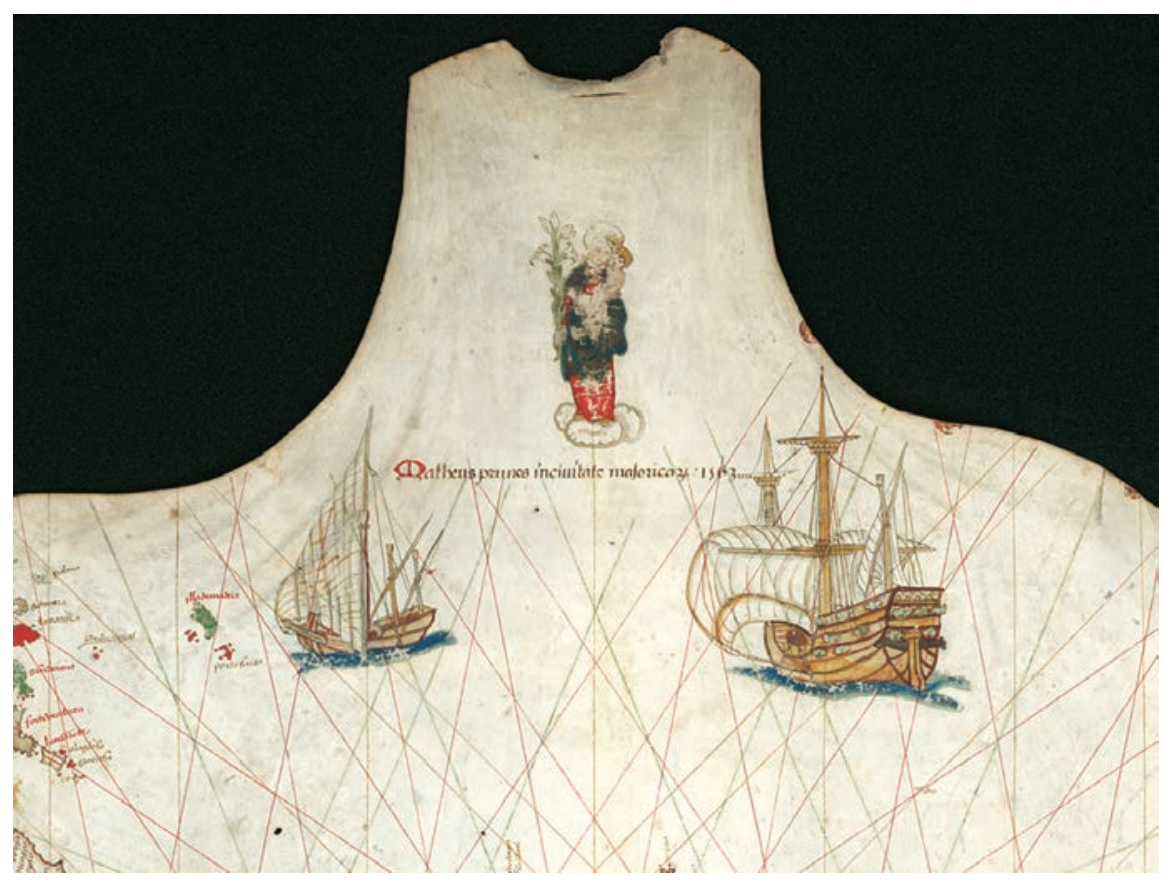

Fig. 10: Carta de Mateu Prunes. Firmada en Mallorca en 1563. Museo Naval de Madrid (Fuente: España. Ministerio de Defensa. Archivo del Museo Naval AMN. PM. 1) la inscripción de una de sus cartas náuticas. 33 Y, a su vez, Pere Rossell se declaró discípulo de Battista Beccari en $1447 .{ }^{34}$

Más dificultades de comprensión presenta el caso de Gabriel Vallseca, de quien hemos pretendido resaltar su significativo papel para las obras posteriores. No disponemos, en este caso, de documentación que le adjudique ningún discípulo. Es más, parece claro que la profesión no se transmitió a sus descendientes, ya que en un documento de 1462 se cita a Vallseca pagando una deuda contraída con su hijo Juan y este figura como mercader de la Ciutat de Mallorca, y sabemos que su otro hijo, de nombre Francisco, también ejerca esta profesión. ${ }^{35}$ No obstante, como ha sido indicado, del número de obras que produjo se infiere un taller con numerosos integrantes. ${ }^{36}$

Durante el siglo XIV, concretamente en el caso del Atlas Català, la importancia de la ilustración de manuscritos como fuente de inspiración parece indudable. Cabe recordar, al respecto, que Cresques Abraham fue esquemático del Atlas Català y también el ornamental presente en las cartas de Vallseca. Además, en la carta náutica de Jaume Olives hecha en Nápoles en 1564 -que se ha citado en relación a la imagen mariana y hagiográficas que presentadestaca claramente la aplicación de valores pictóricos en los elementos arquitectónicos, mediante una acusada aplicación de los juegos de luces y sombras (fig. 9).

\section{LOS CARTÓGRAFOS Y EL ARTE DE LA PINTURA}

Las técnicas utilizadas por los cartógrafos mallorquines procedían, como no podría ser de otro modo, del ámbito de la miniatura, y la principal fuente de inspiración de sus cartas de navegar radicó en la propia cartografía. Ello es evidente en los aspectos geográficos del tema y en la selección de los motivos representados, aunque pensamos que en los aspectos formales las cosas fueron más complejas, como se desprende del análisis artístico que se ha hecho previamente.

En algunos casos, sabemos que la formación de los cartógrafos se realizó en talleres del mismo colectivo. Es el caso documentado de Macià Viladestes, ya que desde la publicación de Llompart de 1989 se sabe de su formación en el taller de Jafudà Cresques. ${ }^{32}$ También sabemos que Arnau Domènech fue discípulo de Pere Rossell, tal como figura en autor de la Biblia Farhi, ${ }^{37}$ y seguramente también de una segunda Biblia que un pariente vendía a otro miembro de la comunidad judía en $1418 .^{38}$ Podría discutirse la validez de la aseveración recordando que las Biblias judías son anicónicas. No obstante, debe recordarse a otro miembro de la familia, Vidal Abraham, quien aparece como autor de las ilustraciones del Llibre de les Franqueses de Mallorca en 1340, libro vinculado a la promoción de Jaime III, último rey de la monarquía mallorquina. 39

Otro caso evidente de la influencia general de la ilustración de manuscritos sobre la cartografía lo tenemos en las cartas de Gabriel Vallseca. Entendemos que se trata de un hecho excepcional por la trayectoria del artista, que ya se ha comentado.

Hemos señalado también influencias puntuales de la pintura sobre tabla en el caso de Viladestes, en su carta de 1413, y más evidentes y constatables en el caso de las cartas de finales del siglo XV y del siglo XVI.

En realidad, las noticias escritas no demuestran ninguna relación de los cartógrafos con ilustradores de otras tipologías de manuscritos, con la única excepción de los Cresques parca en lo que se refiere al arte de la miniatura y de sus autores, es indudable que en Mallorca se hacían libros ilusentre sí. Aunque la documentación es extremadamente

${ }^{32}$ G. LLOMPART MORAGUES, Les il·lustracions religioses de l'Atlas mallorquí del jueu Cresques Abraham, Discurs llegit per l'Ill.lm. Sr. Gabriel Llompart i Moragues, C. R. amb motiu de la seva recepció pública com Acadèmic de Número el dia 23 de maig de 1989 i Contestació de l'Il.lm. Sr. Gabriel Alomar i Esteve. Ed. Reial Acadèmia de Belles Arts de Sant Sebastià, Palma de Mallorca, 1989, p. 6

33 E. J. REY PASTOR, E. GARCÍA CAMARERO, op. cit. (n. 2), p. 84.

${ }^{34}$ M. MILANESI, La cartografia italiana nel Medio Evo e nel Rinascimento, en La cartografía italiana, Barcelona, 1993, p. 15-80. Sobre Battista Beccari:

(...) e uno dei più importanti cartografi catalani del 400, Pere Roselli, si dichiara suo allievo nel 1447, e firma nel 1456 una carta nautica in stile italiano. p. 55

35 G. LLOMPART, op. cit. (n. 5), p. 438-465, doc. 9 y p. 445.

${ }^{36}$ R. PUJADES BATALLER, op. cit. (n. 11), 2009.

${ }^{37}$ El autor de la Biblia Farhi fue identificado por J. RIERA, op. cit. (n. 4). En el contexto de los manuscritos judíos, véase también el análisis de: K. KOGMANAPPEL, Jewish Book Art Between Islam and Christianity: The Decoration of Hebrew Bibles in Medieval Spain, Leiden-Boston, 2004, p. 150-154; K. KOGMANAPPEL, "Elisha ben Abraham. Known as a Cresques": Scribe, Illuminator, and Mapmaker in Fourteenth-Century Mallorca, en Ars Judaica, 10, 20114, p. $27-36$. $3^{8}$ G. LLOMPART, op. cit. (n. 6), v. 1, p. 170, v. 4, doc. 493.

${ }^{39}$ C. A. WILLEMSEN, Algunes notícies sobre un codex de les franquicies de Mallorca a l'Arxiu de la Corona d'Aragó, en Bolletí de la Societat Arqueològica Lul.liana, 22, 1928-29, p. 383, 285; M. DURLIAT, L'Art en el Regne de Mallorca, Palma, 1964, p. 279-286. 
trados de calidad durante el siglo XIV, ${ }^{40}$ como demuestran los encargos del rey Joan I, reconocido bibliófilo, aún antes de acceder al trono.

Dicho esto, a nuestro criterio la situación debió cambiar significativamente a partir de finales del siglo XIV, tal vez por el importante papel que tuvo la comunidad judía en el campo del libro ilustrado, como estudió en su día Marcel Durliat. ${ }^{41}$ El asalto al Call judío en 1391 debió ser un punto de inflexión al respecto. Lo cierto es que la documentación que se conoce relativa a la ilustración de manuscritos y a sus autores es mínima en relación a la existente para la pintura sobre tabla y, además, cabe destacar que, a partir de mediados del siglo XV, las librerías privadas registran abundantes menciones a libros foráneos. ${ }^{42}$ En definitiva, se desprende de la documentación y de las obras conservadas que el arte de la pintura sobre tabla fue la técnica guía en las artes del color de Mallorca, y que la ilustración de manuscritos cayó en franca decadencia, siempre con la significativa excepción de los ejemplares cartográficos objeto de nuestro estudio

Tal vez este papel de la pintura sobre tabla como técnicaguía pueda explicar que, a diferencia de lo que ocurre con los miniaturistas, sí dispongamos de datos documentales -aunque siempre puntuales- que vinculan a los cartógrafos con los pintores. Nos referimos a Rafel Monells y a Bartomeu Olives.

Rafel Monells aparece como pintor de Mallorca entre 1430 y $1438 .{ }^{43}$ En cambio, en 1451 aparece como buxolerius, ${ }^{44}$ es decir, como un artesano que pintaba brújulas, un término que se utilizaba como sinónimo de cartógrafo. Podemos afirmar que combinaba ambas tareas, puesto que en 1461 y en 1465 aparece de nuevo como pintor. ${ }^{45}$ También se le califica con esta denominación en el inventario de bienes que se realiza en 1468, tras su óbito. ${ }^{46}$ De la documentación que se conoce queremos destacar, además, otros puntos que redundan en estas consideraciones. Por una parte, en el inventario de bienes aparecen cartas de navegar -como fue destacado en su día por Llompart- pero también "un retablo de Nuestra Señora no acabado" y otros "tres retablos pequeños aún no acabados”. Pensamos que evidentemente su autor era el propio Monells.

Además, Rafel Monells tuvo vínculos con otros dos pintores conocidos, uno de ellos de mucha relevancia. No son relaciones de trabajo, pero pensamos que son significativas. En primer lugar con Joan Marçol, quien en 1451 vendió su casa al buixoler Rafel Monells. ${ }^{47}$ De Joan Marçol sabemos únicamente de trabajos menores, no obstante, a nuestro juicio formaba parte de una familia relevante en el campo del retablo, como supuesto hijo de Nicolau Marçol y nieto de Pere Marçol, a quien se debe el inicio del gótico internacional en la isla en el campo del retablo y en fechas muy precoces. ${ }^{48}$ Además de con Joan Marçol, Rafel Monells tuvo un estrecho contacto con Joan Rosat, conocido pintor florentino que se instaló en Mallorca a partir de 1447. El contacto se deduce de la aparición de Rosat en el inventario como tutor del hijo de Monells. ${ }^{49}$ Hay que decir que en 1468, Rosat se dedicaba plenamente a actividades relacionadas con la mercadería y que, al parecer, había abandonado poco antes su trabajo como pintor. ${ }^{\circ}$ No obstante, el hecho de que Monells le hubiese nombrado como tutor de su único hijo lleva a pensar que el trato se inició en años anteriores.

El segundo caso significativo es el de Bartomeu Olives u Oliva, tal como aparece indistintamente en la documentación. Según los datos que han sido publicados, relacionándolos en orden cronológico, Olives era ya un pintor importante en 1498, puesto que el portugués Álvaro Viera, ya mayor de edad, se concertó por espacio de un año para aprender en su taller el oficio de pintor, ${ }^{11}$ por lo tanto, se trataba de un contrato de aprendizaje para perfeccionar el oficio. Otros datos de Olives como pintor los tenemos en 1492 y de nuevo entre 1504 y 1532. Entre ellos destaca su posición en los capítulos de la segunda organización del gremio de pintores de 1512, donde aparece en cuarta posición, tras los conocidos Pere Terrencs, Blay Xavery y Joan Desí (Dossi). ${ }^{52}$ En cambio, en 1532 adquirió del mercader Joan Benet treinta docenas de pergaminos, una prueba, según la historiografía, de que compaginaba ambas actividades o de que había abandonado la pintura para dedicarse a la confección de cartas náuticas, una tarea atestiguada por la carta de 1538 actualmente en el Museo Marítimo de Barcelona. En todo caso, se ha colegido su relación con los cartógrafos Olives, la saga que se estableció en Nápoles y Sicilia, de quienes también hemos analizado alguna obra.

Los restantes cartógrafos de la escuela mallorquina que se conocen y que aquí se han citado no aparecen en los capítulos de las cofradías de pintores de 1486 y de pintores y bordadores de 1512.53 Por lo tanto, su actividad no se contemplaba dentro del oficio de pintor. A tenor de lo que se conoce, tampoco eran cartógrafos en el sentido científico

\footnotetext{
${ }^{40}$ G. LLOMPART, op. cit. (n. 6), v. 1, p. 166-172.

${ }^{41}$ M. DURLIAT, op. cit. (n. 39).

${ }^{42}$ T. SABATER, Promoción y orientación del gusto en la pintura de Mallorca. Los siglos del gótico, en Imágenes y promotores en el arte medieval. Miscelánea en homenaje a Joaquín Yarza, Luaces, Bellaterra, 2001, p. 609-617.

${ }^{43}$ Inventario de bienes con carácter fiscal (Capbreu de la creueta): G. LLOMPART, op. cit. (n. 6), v. 4, doc. $19 a$.

${ }^{44}$ Ibidem, doc. 315.

${ }^{45}$ Ibidem, doc. 315 y y 316.

${ }^{46}$ Ibidem, doc. 318 .

${ }^{47}$ Nota 44 .

${ }^{48}$ La documentación sobre Joan Marçol está publicada en: G. LLOMPART, op. cit. (n. 6), v. 4, docs. 274-277. Sobre los Marçol: T. SABATER, op. cit. (n. 29), p. 28-46.

${ }^{49}$ Nota 46

${ }^{50}$ T. SABATER, op. cit (n. 29), p. 226-246.

${ }^{51}$ G. LLOMPART, op. cit. (n. 7), doc. 21.

${ }^{52}$ La documentación de referencia se encuentra publicada en: G. LLOMPART, op. cit. (n. 6), v. 4, docs. 24, 412-415; M. BARCELÓ CRESPÍ y G. LLOMPART, Quaranta dades d'art medieval mallorquí, en Bolletí de la Societat Arqueològica Lul-liana, 1998, p. 85-104, doc. 19.

53 G. LLOMPART, op. cit. (n. 6), v. 1 y 4, p. 122-137, 27-36.
} 
del término, aunque indudablemente algunos cartógrafos (geógrafos-matemáticos) irían marcando las pautas a lo largo del tiempo. Tampoco eran marinos, de ahí que aparezcan como buixolers, una denominación que debió referirse a un oficio propio. En relación al proceso de realización de las cartas, parece que asumieron la totalidad de la obra; es decir, no hubo distinción entre cartografía y pintura sino que todo se resolvió en el mismo ámbito, en la mayoría de casos a partir del proceso de copia de los ejemplares precedentes. Estos rasgos les darían singularidad respecto a otros centros del Mediterráneo, caso concreto de Venecia, donde ha sido señalada la combinación de oficios -especialmente cartógrafos y marineros- y se ha interpretado que las obras resultarían en su mayoría de trabajos en colaboración entre cartógrafos y pintores. ${ }^{54}$

\section{SOBRE PROMOTORES, USOS Y FUNCIONES}

En relación a estos aspectos que se vinculan a la recepción y utilización de las obras, cabe destacar, desde el inicio, que según los datos sobre inventarios y subastas aportados por Hillgarth, ${ }^{55}$ las cartas náuticas estuvieron en la decimonovena posición sobre cincuenta y ocho referencias en cuanto al orden de popularidad de trabajos individuales en las librerías privadas. Como número de ejemplares se conocen documentalmente cincuenta, $y$ las poseyeron treinta y ocho personas, además de otros tres datos referidos a instituciones religiosas, a saber la Catedral y la Cartuja de Valldemossa.

Entre los 38 particulares que promovieron o adquirieron cartas de navegar destacan personas relacionadas con oficios del mar y, muy especialmente, los mercaderes. Desde los inicios se ha destacado esta estrecha conexión entre cartógrafos y mercaderes, quienes al parecer las apreciaron especialmente para abrir nuevas plazas para sus productos y para acceder a otras de determinados territorios. ${ }^{56}$ Sin duda, la utilización práctica de estos objetos contribuyó a su difusión en el ámbito mediterráneo, como también las frecuentes compras por parte de mercaderes italianos, florentinos, genoveses y seguramente también venecianos.

Queremos destacar que las relaciones entre cartógrafos y mercaderes se ampliaron a temas de carácter personal, puesto que en la documentación se constata que actuaron como testigos en actos notariales protagonizados por unos y otros. ${ }^{57}$ En relación a los usos y funciones de las cartas por parte de este sector, queremos avanzar también que, al menos en algunos casos, además de la utilidad práctica fueron también apreciadas como objetos de lujo. Ello incide en la diversa valoración que, al parecer, tuvieron Llompart y Hillgarth sobre el uso de los ejemplares. Mientras Llompart recoge en sus escritos la teoría más común, relativa a que en su mayoría fueron documentos de lujo, de interés para los mercaderes, aunque no se utilizaron nunca para la navegación, podemos leer en Hillgarth que sólo unas pocas fueron así y que en su mayoría se trató de obras sencillas, por lo tanto con finalidad de uso. Para efectuar la distinción, Hillgarth se basa en la calificación como "viejas o utilizadas" que aparece en los registros inventariales..$^{58}$ Ambas posturas o perspectivas sobre el tema no son, a nuestro criterio, excluyentes entre sí.

En nuestra valoración de la cuestión, partimos, por una parte, de que el término "vieja" puede ser sinónimo de antigua, y no de objeto exclusivamente práctico y sin valor artístico, en la acepción actual del concepto. Por otra parte, a partir de estudios sobre inventarios efectuados por Sabater, se pudo constatar que en estos documentos, al igual que en los que conciernen a subastas, no se recogen datos pictóricos sino únicamente datos que afectan a los materiales y a la integridad física de los objetos. ${ }^{59}$ En definitiva, en el campo de la miniatura, las menciones existentes sobre las imágenes de los libros son especialmente escasas hasta finales del siglo XV, y obviamente su no mención no supone su no existencia. Lo mismo ocurre con las referencias a las cartas náuticas en inventarios y registros de subastas de Mallorca: en algunos casos queda claro su nulo valor artístico, siempre en la acepción actual del término, bien porque estén rotas o sólo deboixades, es decir, dibujadas. En otros cabe colegir que estuvieron pintadas, y por lo tanto resultan de interés para la historia del arte. En este punto cabe citar algunas referencias explícitas a cartas pintadas y no deboixades: uno de los casos significativos es el de Rafel Monells, quien poseía cartas pintades ${ }^{60}$ ya que, como hemos comentado, se trataba de un artesano que combinaba la cartografía con la pintura. En un tercer apartado estarían aquellas que, además, contaron con aplicaciones de metales preciosos, en cuyo caso las menciones son totalmente claras al respecto.

Entre las cartas pintadas, tendríamos en primer lugar, la que compró en 1412 el prior de la Cartuja de Valldemossa por 7 libras y 10 sueldos por encargo del prior de la Cartuja de Valldecrist, en Valencia. ${ }^{6}$ Atendiendo al precio que establece Hillgarth para considerarla como objeto de lujo, ${ }^{62}$ no entraría por su precio en esta apreciación. No obstante, sin duda estaba pintada, ya que de hecho ha sido relacionada con la carta de navegar de Macià de Viladestes de 1413, que se conserva en la Biblioteca Nacional de Francia, ${ }^{63}$ que aquí hemos mencionado.

\footnotetext{
54 P. FALCHETTA, op. cit. (n. 22).

55 J. N. HILLGARTH, op. cit. (n. 8), v. I, p. 61-62.

${ }^{56}$ A. HERNANDO, La cartografía mallorquina de la baixa edat mitjana, en A. Hernando et al., op. cit. (n. 9), p. 52. R. J. PUJADES BATALLER, op. cit., (n. 11), 2009, p. 58-66.

${ }^{57}$ Ejemplos significativos en: G. LLOMPART, op. cit. (n. 5), doc. 9, y referencias p. 444. Gabriel Vallseca tuvo también dos hijos, de nombre Joan y Francesc, que se dedicaron a la mercadería: docs. 9-10 y p. 445; G. LLOMPART, op. cit. (n. 6), v. 4, doc. 316; M. BARCELÓ CRESPÍ y G. LLOMPART, op. cit. (n. 52), docs. 11 y 35.

${ }^{58} \mathrm{~J}$. N. HILLGARTH, op. cit. (n. 8), v. I, p. 186-189.

59 T. SABATER, op. cit. (n. 42).

${ }^{60}$ G. LLOMPART, op. cit. (n. 6), v. 4, doc. 318.

${ }^{61}$ J. N. HILLGARTH, op. cit. (n. 8), v. II, doc. C-16.

${ }^{62}$ Ibidem, v. II, p. 187-188.

${ }^{63}$ G. LLOMPART, op. cit. (n. 5), p. 441.
} 
Incluiríamos también una de las dos cartas de navegar que poseía en 1437 Nicolau de Quint, un miembro de la oligarquía local, quien aparece en el inventario como mercader y ciudadano. Además de una carta pocha, sguinçada que, por lo tanto, debía carecer de interés, tiene una segunda de la que no se citan materiales preciosos pero que es calificada como molt bela, ab les sues sestes. ${ }^{64}$ Ya que el término sestes se refiere a instrumentos de navegación, ${ }^{65}$ pensamos que se trata de un caso prototípico de uso práctico de una obra que no entra en contradicción con el carácter estético.

En 1479 el doncel Joan de Tagamanent tenía también una carta pintada, ${ }^{66}$ al igual que el notario Miquel Abellar en 1493, quien además poseía una "Cosmografía de Tolomeo, pintada". ${ }^{67}$ También podría ser el caso del clérigo Joan de Palou quien, por los daños sufridos entre 1521 y 1523 por la rebelión de las Germanías, reclama el valor de un mapamundi, calificado como "muy bello", con un precio de 10 libras. ${ }^{68}$ Otros casos de cartas pintadas las relacionamos con las menciones específicas a mapamundis. En la subasta de los bienes del Canónigo e Inquisidor Gregori Genovard, figura un mapamundi que se vende por 5 libras y 7 sueldos. ${ }^{69} \mathrm{Y}$ en 1543 el honorable Pere Cabrer, mercader, tiene un único libro en su estudio, un mapamundi de papel..$^{70}$

Aquellas cartas de navegar que, además de estar pintadas, constituyeron en su tiempo objetos de lujo porque contenían materiales ricos, especialmente aplicaciones crisográficas, las contemplamos bien por la mención específica de estos materiales en los inventarios, o bien por el elevado precio que alcanzaron en las subastas.

En orden cronológico, pertenecería a este apartado la carta de navegar hecha sobre pergamino que en 1408 se subastó por 20 libras. Los bienes eran del mercader Joan de Puig y el comprador fue un tal Niccola di Giovanni..$^{71}$ Un siglo después, en 1506, tendríamos la carta de navegar del mercader Miquel Garau, ya que se describe como gran, en que son les ciutats e regnes novament trobats, ab son garniment cuberta de tela blava. ${ }^{22}$ Además de esta mención al garniment, que entendemos en su definición de engaste de oro, plata u otro metal, destacamos el interés iconográfico, puesto que se destaca la renovación en cuanto a los contenidos geográficos. Como se ha dicho, la actualización en contenidos en estas cartas era especialmente valorada desde los inicios por parte de sus promotores.

También en la ya mencionada reclamación por los daños sufridos con las Germanías, aparece una doble demanda del abogado Jaume Montanyans, referida a una carta de navegar tota daurada e molt pintada, por la cual requiere 24 libras, y a una segunda del mismo precio que figura descrita como carta de navegar, nova, en la quall havie la terra de Calicu $i$ les illes trobades.73

Finalmente, incluiríamos el mapamundi que poseían en 1539 Joanot y Jaume Sanglés, listados en el inventario de su padre que era un orfebre. ${ }^{74}$ Se especifica que en el comedor tienen un mapamundi $a b$ son gorniment. Como se ha dicho entendemos el término gorniment como engaste de materiales preciosos. Y no deja de ser significativo que sea el único libro que tenían en el comedor en lugar de en el estudio, hecho que podría probar una utilización específica como objeto de decoración.

En esta reseña hemos excluido algunas referencias porque las entradas son simples menciones, sin ningún dato descriptivo que permita deducir el carácter de las obras o bien sus aspectos artísticos. Sin embargo, quisiéramos finalizar con una última observación. Tal como comentó en su día Jocelyn Hillgarth, los propietarios de cartas de navegar -sea cual fuere la condición de las obras en cuanto objeto artístico-fueron mayoritariamente personas relacionadas de una manera u otra con el tráfico marítimo. ${ }^{75}$ En cambio, desde finales del siglo XV aparecen citadas también en colecciones pertenecientes a miembros de la nobleza, procuradores, juristas y otros profesionales liberales. Ello indica que, sea cual fuere su uso, se incorporaron a las colecciones bibliográficas de la élite mallorquina.

\footnotetext{
${ }^{64}$ J. N. HILLGARTH, op. cit. (n. 8), v. II, doc. 207-1/14.

${ }^{65}$ La sesta era un compás de puntas que implicaba otro principio técnico, la escala, incorporada obligatoriamente a las cartas de forma gráfica. V. M. ROSSELLÓ VERGER, Cartografia i navegació, segles XIII-XV, en A. Bonner y F. Bujosa Homar (dir.), Història de la Ciència a les Illes Balears, vol. 1 (l'Edat Mitjana), Palma de Mallorca, 2006, p. 261.

${ }^{66} \mathrm{~J}$. N. HILLGARTH, op. cit. (n. 8), v. II, doc. 345-10.

${ }^{67}$ Ibidem, doc. 401-44/422.

${ }^{68} \mathrm{Ibidem}$, doc. 674 bis-N.

${ }^{69}$ Ibidem, doc. 778-6.

${ }^{70}$ Ibidem, doc. 868.

${ }^{71}$ G. LLOMPART, op. cit (n. 5), p. 449.

${ }^{72}$ J. N. HILLGARTH, op. cit. (n. 8), v. II, doc. 490-1.

${ }^{73}$ Ibidem, doc. 674 bis-H.

${ }^{74}$ Ibidem, doc. 821-14.

75 Ibidem, v. I, p. 186-189.
} 


\begin{tabular}{|c|c|c|c|}
\hline AUTOR & FIRMADA EN & DATACIÓN & UBICACIÓN \\
\hline $\begin{array}{l}\text { Atlas Català } \\
\text { Cresques Abraham y Jafudà } \\
\text { Cresques }\end{array}$ & Mallorca & 1375 & Bibliothèque Nationale de France \\
\hline Macià de Viladestes & Mallorca & 1413 & Bibliothèque Nationale de France \\
\hline Gabriel de Vallseca & Mallorca & 1439 & Museo Marítimo de Barcelona \\
\hline Gabriel de Vallseca (atr.) & Mallorca & c. 1440 & Biblioteca Nazionale, Firenze \\
\hline Gabriel de Vallseca & Mallorca & 1447 & Bibliothèque Nationale de France \\
\hline Pere Rossell & Mallorca & 1447 & Biblioteca Guarnacci, Volterra. \\
\hline Gabriel de Vallseca & Mallorca & 1449 & Archivio di Stato, Firenze \\
\hline Pere Rossell & & 1464 & $\begin{array}{l}\text { Germanisches Nationalmuseum, } \\
\text { Nürnberg }\end{array}$ \\
\hline Pere Rossell & & 1465 & British Library, London. \\
\hline Pere Rossell & Mallorca & 1466 & $\begin{array}{l}\text { James Ford Bell Library, University } \\
\text { of Minnesota }\end{array}$ \\
\hline Pere Rossell & & $\begin{array}{l}\text { Segunda mitad del } \\
\text { siglo XV }\end{array}$ & $\begin{array}{l}\text { University of Yale (Estados Uni- } \\
\text { dos) }\end{array}$ \\
\hline Jaume Bertran & Mallorca & 1482 & Archivio di Stato, Firenze. \\
\hline Arnau Domènech & Nápoles & 1486 & $\begin{array}{l}\text { National Maritim Museum, Lon- } \\
\text { dres }\end{array}$ \\
\hline Jaume Bertran & Mallorca & 1489 & Biblioteca Marucelliana, Firenze \\
\hline Pere Russo & Messina & 1508 & Museo Marítimo de Barcelona \\
\hline Pere Russo & Génova & 1511 & Bibliothèque Nationale de France \\
\hline Pere Russo & & 1516 & Bibliothèque Nationale de France \\
\hline Jaume Russo & Messina & 1533 & Nationaal Archief, Nederland \\
\hline Jaume Russo & Messina & 1535 & $\begin{array}{l}\text { Biblioteca de la Fundación March } \\
\text { de Palma }\end{array}$ \\
\hline Bartomeu Olives/Oliva & Mallorca & 1538 & Museu Marítim de Barcelona. \\
\hline Jaume Olives/Oliva & Messina & 1559 & Biblioteca Nazionale di Napoli \\
\hline Mateu Prunes & Mallorca & 1561 & $\begin{array}{l}\text { Biblioteca de la Fundación March } \\
\text { de Palma }\end{array}$ \\
\hline Mateu Prunes & Mallorca & 1563 & Museo Naval de Madrid \\
\hline Jaume Olives/Oliva & Nápoles & 1564 & $\begin{array}{l}\text { Biblioteca de la Fundación March } \\
\text { de Palma }\end{array}$ \\
\hline Mateu Prunes & Mallorca & 1571 & $\begin{array}{l}\text { Museo del Castello di Albertis di } \\
\text { Genova }\end{array}$ \\
\hline Jaume Olives/Oliva & Barcelona & 1571 & $\begin{array}{l}\text { Biblioteca de la Fundación March } \\
\text { de Palma }\end{array}$ \\
\hline Bartomeu Olives/Oliva II & Messina & 1584 & Bibliothèque Nationale de France \\
\hline Joan Olives/Oliva & Messina & 1595 & Bibliothèque Nationale de France \\
\hline
\end{tabular}

